\title{
Polimorfisme Gen Apolipoprotein E Pada Penderita Sindrom Down Trisomi 21
}

\author{
Malinda Meinapuri
}

\begin{abstract}
Abstrak
Latar Belakang: Sindrom Down merupakan suatu kelainan kromosom yang ditandai dengan adanya baik seluruhnya (trisomi 21) maupun sebagian (translokasi) suatu salinan tambahan kromosom ke 21. Apolipoprotein $E$ (APOE) merupakan suatu bentuk protein polimorfik yang disandikan oleh suatu gen yang berlokasi pada lengan panjang kromosom 19 pada posisi 13.2 (19q13.2). Polimorfism gen APOE berkaitan dengan meningkatnya frekuensi alel $\varepsilon 4$ yang berakibat terjadinya hambatan dalam percabangan dan pertumbuhan neuron. Dimungkinkan, penderita Sindrom Down Trisomi 21 memiliki gen APOE yang berbeda dengan kontrol sebagai faktor yang dapat mengakibatkan penuaan dini otak.

Metode : Penelitian ini merupakan penelitian kasus kontrol untuk mengamati perbedaan distribusi dan frekuensi alel dan genotip gen APOE pada penderita Sindrom Down trisomi 21 dibandingkan dengan kontrol. Kasus Sindrom Down dan kontrol diambil dari data sekunder yang tersimpan di Center for Biomedical Research (CEBIOR) Semarang Indonesia. Ekstraksi DNA dilakukan dengan menggunakan metode yang terdapat di (CEBIOR) Semarang Indonesia. Kegiatan selanjutnya adalah pemeriksaan polimorfisme gen Apolipoprotein E dengan mengunakan teknik PCR dan RFLP.

Hasil

: Sebanyak 33 sampel dari penderita Sindrom Down, 18 laki-laki dan 15 perempuan dan 33 sampel kontrol, 18 laki-laki dan 15 perempuan. Baik sampel Sindrom Down maupun kontrol memiliki frekuensi alel $\varepsilon 3$ paling tinggi dibandingkan dengan alel $\varepsilon 2$ dan $\varepsilon 4$. Pada Sindrom Down didapatkan alel $\varepsilon 44$ sampel $(6,1 \%)$ dan alel $\varepsilon 28$ sampel (12,1\%). Baik sampel Sindrom Down maupun kontrol memiliki genotip $\varepsilon 3 / \varepsilon 3$ paling tinggi dibandingkan dengan genotip gen APOE lainnya. Pada Sindrom Down didapatkan genotip $\varepsilon 2 / \varepsilon 44$ sampel $(12,1 \%)$ dan genotip $\varepsilon 2 / \varepsilon 22$ sampel $(6,1 \%)$.

Simpulan $\quad:$ Terdapat perbedaan distribusi alel dan genotip gen APOE pada penderita Sindrom Down trisomi 21 dibandingkan dengan kelompok kontrol. Diperlukan analisis sampel yang lebih banyak untuk mengkonfirmasi hasil penelitian ini.
\end{abstract}

Kata kunci: Sindrom Down, Polimorfisme, Apolipoprotein E.

\begin{abstract}
Backgrounds :Down syndrome is an abnormal chromosomal condition, characterized by the presence of all (trisomy 21) or part (such as due to translocations) of a third copy of chromosome 21. Apolipoprotein $E$ (APOE) is a polymorphic protein coded by a gene located on the long arm (q) of chromosome 19, positioning at 13.2 (19q13.2). Polymorphism of APOE gene is related with the increasing of allele $\varepsilon 4$ 's frequency thus cause obstruction in neuron ramification and development. In previous study, Down Syndrome groups are having different type of APOE gene compared with control. That why it can be considered as one of the caused premature aging of brain. Methods This is a case control study to observe the difference of distribution and frequency of APOE gene allele and genotype in Down Syndrome Trysomi 21 compared to control. Down Syndrome and control samples was taken as secondary data from Center for Biomedical Research (CEBIOR) Semarang Indonesia. DNA extraction was done by using the commonly used salting out method in CEBIOR Semarang Indonesia. Subsequently polimorphism of APOE gene analysis has been done by using PCR and RFLP.Result : Thirty three samples were Down Syndrom patients, consist of 18 male and 15 female. Thirty three samples are control, consist of 18 male and 15 female. Both groups were having the highest frequency of allele $\varepsilon 3$ compared to allele $\varepsilon 2$ and $\varepsilon 4$. In Down Syndrome, frequency of $\varepsilon 4$ allele was found in 4 samples $(6,1 \%)$ while allele $\varepsilon 2$ was found in 8 samples $(12,1 \%)$. Genotype $\varepsilon 3 / \varepsilon 3$ were the highest frequency on both group compared to the other. In Down Syndrome group identified $\varepsilon 2 / \varepsilon 4$ genotype in 4 samples $(12,1 \%)$ and $\varepsilon 2 / \varepsilon 2$ genotype in 2 samples (6,1\%). Conclusion : There is slight difference distribution of APOE gene allele and genotype in Down Syndrome Trysomi 21 compared to control. More samples should be analyzed to confirm this finding.
\end{abstract}

Keywords:Down Syndrome, Polymorpism, Apolipoprotein E.

Affiliasi penulis : Malinda Meinapuri, Bagian Histologi FK UNAND Padang

email : meinapurimalinda@yahoo.co.id Telp : 0751-39926

\section{PENDAHULUAN}

Sindrom Down merupakan salah satu penyakit kelainan kromosom dengan penyebab yang sangat kompleks. Sindrom Down ditandai dengan adanya interaksi secara menyeluruh maupun sebagian antara triplikasi kromosom 21 dan faktor - faktor lainnya yang dapat memegang peranan dalam gejala klinis pada penderita, seperti apolipoprotein E (APOE) (19q13.2) yang merupakan kandidat gen yang berinteraksi dengan deposisi Abeta otak menjadi salah satu penanda kelainan neurologis pada penderita Sindrom Down.

Insidensi Sindrom Down diperkirakan 1/800 sampai 1/1000 kelahiran hidup dan dapat terjadi pada semua suku bangsa dan di antara semua tingkatan sosial ekonomi. ${ }^{1}$ Terdapat beberapa variasi genetika yang dapat menjadi penyebab Sindrom Down antara lain trisomi 21 klasik, Sindrom Down Mosaik, dan tranlokasi Sindrom Down. Namun hingga saat ini 
penyebab pasti dari penambahan jumlah kromosom 21 pada kasus Sindrom Down belum diketahui dan masih menjadi hal yang terus menerus diteliti dalam pengembangan ilmu kedokteran. ${ }^{2,3}$

Defek tulang, brakhisefalus, gambaran dismorfik kraniofasial, defek septum atrioventrikular, stenosis katup dan abnormalitas sistem gastrointestinal merupakan sejumlah defek perkembangan sering ditemukan pada penderita Sindrom Down. Selain itu, perubahan perkembangan otak dan disabilitas intelektual selalu terjadi pada Sindrom Down trisomi 21. Sehingga penderita Sindrom Down memiliki kemampuan kognitif yang lebih rendah dari kemampuan rata-rata, biasanya terjadi dari kadar ringan sampai berat dan IQ rata-rata adalah sekitar 50 , dibandingkan dengan anak normal yang memiliki IQ $100 .^{4,5}$

Apolipoprotein E (APOE) merupakan suatu bentuk protein polimorfik yang disandikan oleh suatu gen yang berlokasi pada kromosom 19q13.2.Di otak, $A P O E$ merupakan protein mayor, produksi dan akumulasinya meningkat pada gangguan sistem saraf pusat dan cedera saraf tepi. APOE mempunyai kemampuan untuk berinteraksi dengan reseptor $L D L$ yang berkaitan dengan protein sehingga APOE mempunyai peran sentral dalam metabolisme lipoprotein plasma dan homeostatis kolesterol. ${ }^{6}$

Gen APOE secara lazim memiliki tiga alel, yaitu alel $\varepsilon 2$, $\varepsilon 3$, dan $\varepsilon 4$. Polimorfisme gen $A P O E$ berkaitan dengan meningkatnya frekuensi alel $\varepsilon 4$ yang berakibat terjadinya hambatan dalam percabangan dan pertumbuhan neuron, hal ini dapat mengakibatkan banyak neuron mengalami degenerasi dan terbentuk plak amiloid yang akhirnya berujung pada penuaan dini otak. ${ }^{1,5-8}$

Adanya polimorfisme gen $A P O E$ yang berkaitan erat dengan peningkatan frekuensi alel $\varepsilon 4$ ini mengakibatkan penuaan dini otak penderita Sindrom Down yang juga merupakan faktor pencetus munculnya penyakit Alzheimer. ${ }^{5,7}$ Hampir pada semua penderita Sindrom Down setelah berumur 35 tahun ditemukan adanya plak amilod dan kekusutan neurofibriler pada otaknya seperti yang dijumpai pada penderita demensia Alzheimer, sehinggga diperkirakan setelah berumur 35 tahun lebih dari $25 \%$ penderita Sindrom Down sudah menunjukkan gejalagejala demensia Alzheimer dan dengan meningkatnya umur maka kecenderungan ini akan semakin bertambah. ${ }^{9,10}$ Dibandingkan dengan populasi normal, insidensi penyakit alzheimer pada penderita Sindrom Down 3 sampai 5 kali lebih banyak dan awitan demensia pada penderita Sindrom Down cenderung lebih awal, rata-rata kemunculannya lebih cepat 20 tahun (sekitar umur 30-40 tahun) dibandingkan masyarakat umum (sekitar 40-60 tahun), namun dengan kecenderungan tersebut tidak semua penderita Sindrom Down akan menderita penyakit demensia Alzheimer. ${ }^{10}$ Jika dibandingkan antara jenis kelamin, maka penderita Sindrom Down wanita mempunyai resiko lebih besar daripada penderita Sindrom Down laki-laki untuk menderita penyakit Alzheimer. ${ }^{10,11}$

Sampai saat ini belum ada penelitian tentang polimorfisme gen $A P O E$ pada penderita Sindrom Down trisomi 21 yang kemungkinan berkaitan dengan proses penuaan pada penderita ini di Indonesia. Untuk alasan tersebut maka dilakukan analisa polimorfisme gen $A P O E$ pada penderita Sindrom Down trisomi 21 dibandingkan dengan populasi normal yang diwakili dengan kelompok kontrol.

\section{METODA}

Penelitian ini merupakan penelitian kasus kontrol untuk mengamati polimorfisme gen $A P O E$ pada penderita Sindrom Down trisomi 21 dibandingkan dengan kelompok kontrol. Pengumpulan darah sampel, analisis sitogenetika, ekstraksi DNA telah dilakukan pada penelitian sebelumnya. Ekstraksi DNA dilakukan dengan menggunakan metode yang terdapat di Center for Biomedical Research (CEBIOR) Semarang Indonesia. Kegiatan selanjutnya adalah pemeriksaan polimorfisme gen Apolipoprotein $\mathrm{E}$ dengan mengunakan teknik PCR dan RFLP.

Pada proses PCR, sebanyak $25 \mu$ l campuran PCR yang terdiri dari Buffer PCR, $\mathrm{MgCl}_{2}$, dNTPs, primer Forward ${ }^{5}$, primer Reverse ${ }^{5}$, enzim TAG dan DNA diamplifikasi dengan menggunakan mesin PCR Aplied Biosystem sebanyak 35 siklus, kemudian dielektroforesis pada agarose $1 \%$ dengan tegangan 100volt selama 1 jam. Besar produk PCR yang dihasilkan adalah 227bp. Produk PCR 227 bp dipotong dengan mengunakan 3 unit enzim Hhal yang akan memotong pada sekuens 5...GCGC...3'. Produk PCR yang sudah dipotong oleh enzim Hhal ditanam pada gel agarose $4 \%$, kemudian dilanjut dengan proses elektroporesis mengunakan tegangan 70 volt selama 1 jam dan diphoto dibawah sinar ultraviolet setelah pengecatan dengan ethidium bromide. ${ }^{5}$

\section{HASIL}

Penelitian ini melibatkan 66 sampel, dimana 33 sampel dari penderita Sindrom Down dan 33 sampel dari populasi kontrol normal. Dari 33 sampel penderita Sindrom Down tersebut, sebanyak 18 sampel (54,5\%) adalah laki-laki dan 15 sampel $(45,5 \%)$ adalah perempuan. Sedangkan dari 33 sampel yang mewakili populasi normal, persentase yang sama ditemukan pada perbandingan sampel lakilaki dan perempuan yaitu sebanyak 18 sampel $(54,5 \%)$ adalah laki-laki dan 15 sampel $(45,5 \%)$ adalah perempuan.

Tabel 1. Karasteristik sampel

\begin{tabular}{lcc}
\hline Karakteristik & $\begin{array}{c}\text { Sindrom Down } \\
\mathbf{n}(\%)\end{array}$ & $\begin{array}{c}\text { Kontrol } \\
\mathbf{n}(\%)\end{array}$ \\
\hline Jenis kelamin & & \\
Laki-laki & $18(54,5)$ & $18(54,5)$ \\
Perempuan & $15(45,5)$ & $15(45,5)$ \\
& & \\
Umur & & \\
Mean & 16,697 & 15,303 \\
SD & 4,073 & 2,053 \\
Median & 16,00 & 15,00 \\
Maximum & 26,00 & 19,00 \\
Minimum & 10,00 & 11,00 \\
\hline
\end{tabular}

Diagnosis Sindrom Down berdasarkan karakteristik fisik dan analisis kariotipik, dimana seluruh sampel penderita Sindrom Down memiliki kariotip trisomi 21 $(47, X Y,+21 / 47, X X,+21)$. Keseluruhan sampel, baik sampel dari penderita Sindrom Down maupun sampel dari populasi normal berasal dari etnik yang sama.

Sampel penderita Sindrom Down terdapat variasi sebaran alel, dimana ditemukan alel $\varepsilon 4$ dan $\varepsilon 2$ walaupun frekuensi alel $\varepsilon 3$ tetap merupakan frekuensi 
alel yang terbanyak. Sementara itu pada keseluruhan sampel yang mewakili populasi kontrol normal ditemukan alel $\varepsilon 3$ dan tidak ditemukan alel $\varepsilon 2$ dan $\varepsilon 4$. Sebaran frekuensi alel gen $A P O E$ seperti terlihat pada tabel 2.

Tabel 2. Frekuensi alel gen $A P O E$

\begin{tabular}{ccccccc}
\hline Alel & \multicolumn{2}{c}{$\begin{array}{c}\text { Sindrom } \\
\text { Down }\end{array}$} & Kontrol & \multicolumn{2}{c}{$\begin{array}{c}\mathrm{RR} \\
(95 \%\end{array}$} & $\mathrm{P}$ \\
\cline { 2 - 5 } & $\mathrm{n}$ & $\%$ & $\mathrm{n}$ & $\%$ & $\mathrm{Cl})$ & \\
\hline$\varepsilon 2$ & 12 & 18,2 & 0 & 0 & 2,222 & 0,000 \\
dan & & & & & $\begin{array}{c}1,823- \\
2,708\end{array}$ & \\
$\varepsilon 4$ & & & & & 2,708 & \\
$\varepsilon 3$ & 54 & 81,8 & 66 & 100 & & \\
\hline Total & 66 & 100 & 66 & 100 & & \\
\hline
\end{tabular}

Dari tabel diatas dapat diambil kesimpulan bahwa "terdapat perbedaan antara frekuensi alel gen $A P O E$ pada penderita Sindrom Down dan kontrol", $p=0.000$

Sebelum dipotong dengan menggunakan enzim Hhal pada proses RFLP, produk gen APOE yang dihasilkan pada proses PCR adalah sebesar 227 bp. Gambaran hasil PCR penderita Sindrom Down seperti terlihat pada gambar 1 .

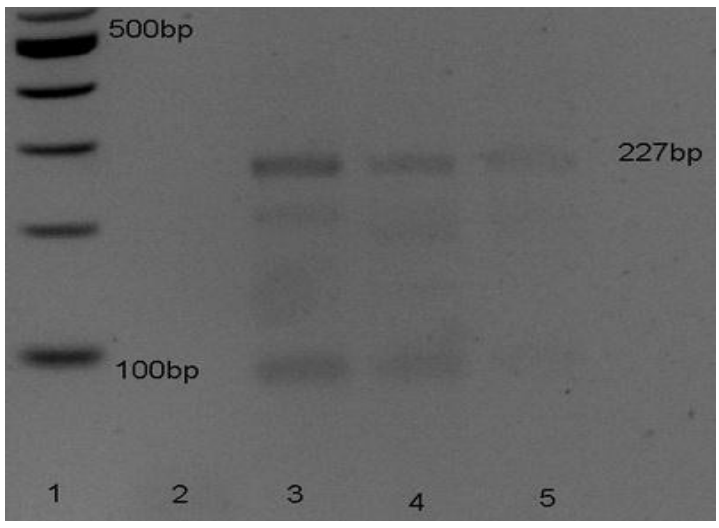

Gambar 1. Gambar hasil PCR penderita Sindrom Down. Lajur 1: marker, lajur 2 : blangko, lajur 3,4 , dan 5 : sampel Sindrom down menghasilkan produk sebesar $227 \mathrm{bp}$.

Sampel penderita Sindrom Down terdapat variasi sebaran alel, dimana ditemukan alel $\varepsilon 2$ pada lajur 1 dan 9 dan $\varepsilon 4$ pada lajur 5,6,7 dan 8. Sementara sampel yang lain menunjukkan alel $\varepsilon 3$. Gambaran hasil RFLP penderita Sindrom Down seperti terlihat pada gambar 2 .

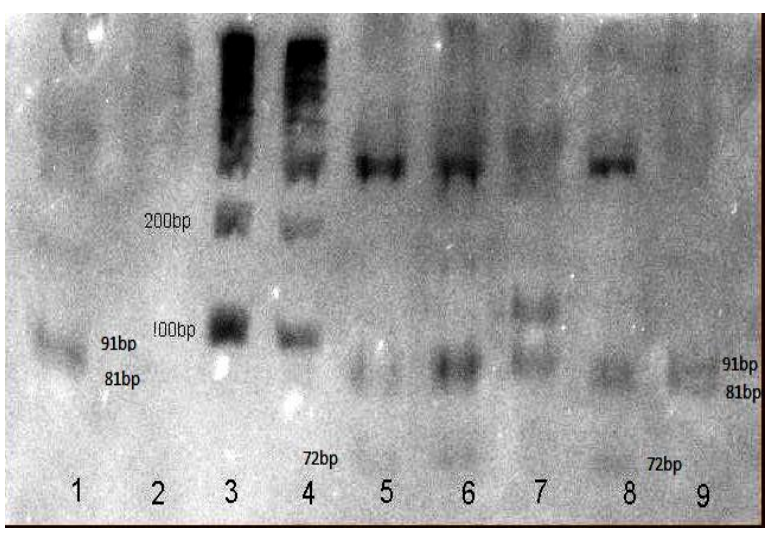

Gambar 2. Gambaran hasil RFLP penderita Sindrom Down pada media polyacrilamide $15 \%$. Lajur 1dan 9: memiliki potongan pada fragmen 91 bp dan 81 bp memiliki alel $\varepsilon 2$ dan genotip $\varepsilon 2 / \varepsilon 2$, , lajur 2 : blangko, lajur 3 dan 4 : marker, lajur 5-8: , lajur 5-8: memiliki potongan pada fragmen $91 \mathrm{bp}, 81 \mathrm{bp}$, dan $72 \mathrm{bp}$ memiliki alel $\varepsilon 2$ (potongan pada fragmen 91 bp dan 81 bp) dan alel $\varepsilon 4$ (potongan pada fragmen $91 \mathrm{bp}$ dan 72 bp) sehingga memiliki genotip heterozigot $\varepsilon 2 / \varepsilon 4$.

Menarik disini (gambar 2) pada jalur 7 didapatkan juga extra band pada \pm 130 bp yang seharusnya tidak dikenali oleh enzim Hhal sehingga dimungkinkan terdapat mutasi didaerah lain pada gen APOE yang tidak umum. Perlu dilakukan sequensing untuk mengkonfirmasi hal ini.

Sementara pada sampel kontrol tidak terdapat variasi sebaran alel, ditemukan alel $\varepsilon 3$ pada keseluruhan sampel. Gambaran hasil RFLP sampel kontrol seperti terlihat pada gambar 3.

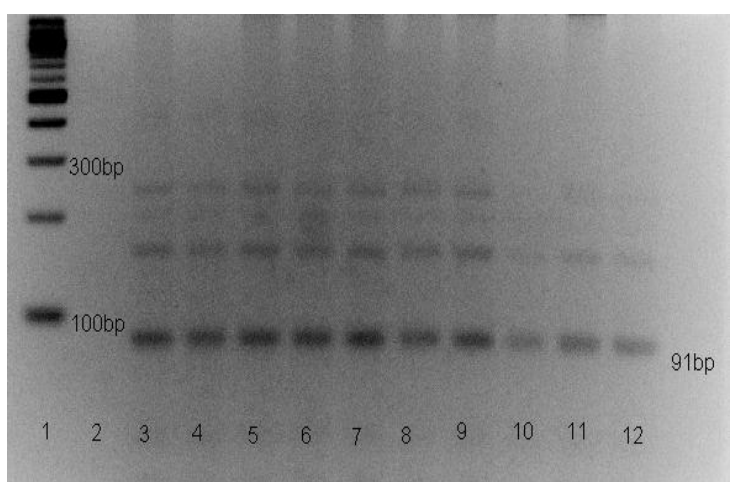

Gambar 3. Gambar hasil RFLP pada populasi kontrol. Lajur 1: marker, lajur 2 : blangko, lajur 3-12 : sampel kontrol memiliki potongan pada fragmen $91 \mathrm{bp}$ memiliki alel $\varepsilon 3$ dan genotip $\varepsilon 3 / \varepsilon 3$.

Sebaran frekuensi kombinasi genotip gen $A P O E$ seperti terlihat pada tabel 3. Sampel penderita Sindrom Down memiliki sebaran dengan frekuensi terbanyak pada genotip $\varepsilon 3 / \varepsilon 3$, selain itu terdapat sebaran genotip $\varepsilon 2 / \varepsilon 2$ dan $\varepsilon 2 / \varepsilon 4$. Sementara Seluruh sampel yang mewakili populasi kontrol normal memiliki genotip $\varepsilon 3 / \varepsilon 3$.

Tabel 3. Frekuensi kombinasi genotip gen $A P O E$

\begin{tabular}{ccccccc}
\hline \multirow{2}{*}{ Genotip } & \multicolumn{2}{c}{$\begin{array}{c}\text { Sindrom } \\
\text { Down }\end{array}$} & Kontrol & $\begin{array}{c}\mathrm{RR} \\
(95 \%\end{array}$ & $\mathrm{p}$ \\
\cline { 2 - 5 } & $\mathrm{N}$ & $\%$ & $\mathrm{n}$ & $\%$ & $\mathrm{Cl})$ & \\
\hline$\varepsilon 2 / \varepsilon 2, \varepsilon 2 / \varepsilon 3, \varepsilon 2 / \varepsilon$ & 6 & 18, & 0 & 0 & 2,222 & 0,024 \\
$4, \varepsilon 3 / \varepsilon 4$, & & 2 & & & 1,680 & \\
dan $\varepsilon 4 / \varepsilon 4$ & & & & & - & \\
$\varepsilon 3 / \varepsilon 3$ & 27 & 81, & 3 & 10 & 2,940 & \\
& & 8 & 3 & 0 & & \\
\hline Total & 33 & 10 & 3 & 10 & & \\
& & 0 & 3 & 0 & & \\
\hline
\end{tabular}

Dari tabel diatas dapat diambil kesimpulan bahwa "terdapat perbedaan antara kombinasi genotip gen APOE pada penderita Sindrom Down dan kontrol", $\mathrm{p}=0,024$

\section{PEMBAHASAN}

$A P O E$ merupakan suatu gen dengan bentuk polimorfik yang berlokasi pada lengan panjang kromosom 19 (19q13.2). ${ }^{12,13}$ APOE memiliki tiga alel gen yaitu alel $\varepsilon 2$, alel $\varepsilon 3$ dan alel $\varepsilon 4$. Alel - alel tersebut dibedakan antara satu dengan yang lain oleh substitusi asam amino tunggal pada posisi 112 dan 158. Alel $\varepsilon 2$ memiliki sistein pada posisi 112 dan 158 dalam region ikatan reseptor, alel $\varepsilon 3$ memiliki sistein 
pada posisi 112 dan arginin pada posisi 158 sementara alel $\varepsilon 4$ memiliki arginin pada kedua sisinya. ${ }^{14,15}$

Enzim yang digunakan pada penelitian in adalah Enzim Hhal yang akan memotong pada sekuens 5...GCGC...3', jika individu dengan alel $\varepsilon 2$, DNA akan terpotong 5 fragmen yang berukuran 21 bp,16 bp,91 bp,18 bp dan 81 bp. Jika individu dengan alel $\varepsilon 3$, DNA akan terpotong 6 fragmen yang berukuran 21 bp,16 bp,91 bp,18 bp,48 bp dan 33 bp. Jika individu dengan alel $\varepsilon 4$, DNA akan terpotong 7 fragmen yang berukuran 21 bp,16 bp,19 bp,72 bp,18 bp,48 bp dan 33 bp. ${ }^{5}$

Sekuen gen APOE alel $\varepsilon 3$ terlihat sebagai berikut ${ }^{15}$

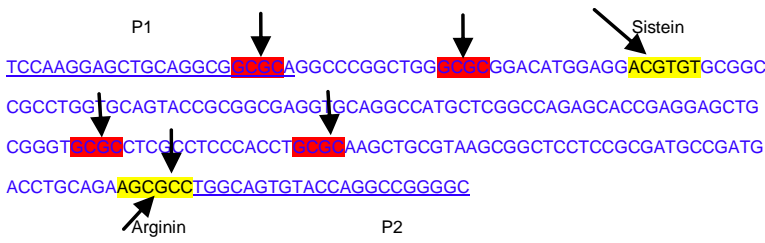

Sekuen gen APOE alel $\varepsilon 2$ terlihat sebagai berikut ${ }^{15}$

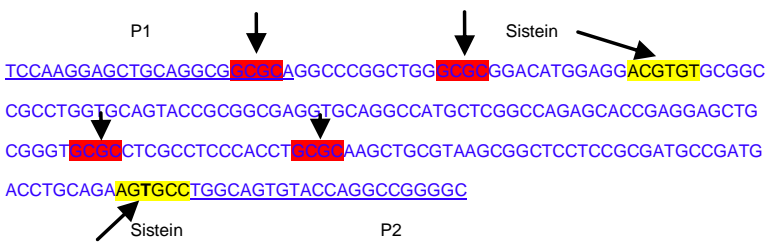

Sekuen gen APOE alel $\varepsilon 4$ terlihat sebagai berikut ${ }^{15}$

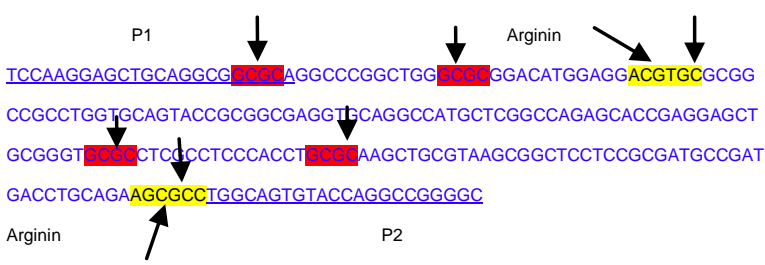

Secara keseluruhan, baik sampel penderita Sindrom Down maupun sampel kontrol memiliki frekuensi alel $\varepsilon 3$ paling tinggi dibandingkan dengan frekuensi alel $\varepsilon 2$ dan $\varepsilon 4$. Hal ini terlihat dari tabel 2 yang menunjukkan bahwa pada penderita Sindrom Down frekuensi alel $\varepsilon 3$ gen APOE sebesar 54 sampel (81,8\%). Sementara pada kontrol $100 \%$ memiliki alel $\varepsilon 3$.

Alel $\varepsilon 3$ merupakan suatu bentuk isoform predominan yang ditemukan pada mayoritas populasi yaitu sekitar $70-80 \%$. ${ }^{16}$ Alel $\varepsilon 3$ merupakan alel yang normal dan belum mengalami substitusi asam amino pada posisi 112 dan 158. ${ }^{15}$ Alel $\varepsilon 3$ pada manusia berfungsi untuk mempertahankan dan memelihara pertumbuhan neuron terutama pada ganglion dorsalis, sehingga alel $\varepsilon 3$ pada manusia dengan $\beta$-Very Low Density Lipoprotein $(\beta-V L D L)$ bersifat protektif terhadap kejadian neurodegeneratif dan gangguan behavior. ${ }^{17}$

Ditemukan alel $\varepsilon 4$ pada sampel penderita Sindrom Down. Hal ini terlihat dari tabel 2 yang menunjukkan sebaran frekuensi alel gen $A P O E$ alel $\varepsilon 4$ memiliki frekuensi sebesar 4 sampel (6,1\%). Sementara pada kelompok kontrol, tidak ditemukan alel $\varepsilon 4(0 \%)$.

Alel $\varepsilon 4$ ditemukan sekitar $10-15 \%$ dari populasi. ${ }^{16}$ Alel $\varepsilon 4$ merupakan alel gen APOE yang telah mengalami substitusi asam amino pada posisi ke 112 yang pada mulanya memiliki rangkaian basa ACGTGT menjadi ACGTGC, sehingga asam amino yang semula sistein pada posisi tersebut berubah menjadi arginin. Sedangkan pada posisi ke 158 rangkaian basanya tetap AGCGCC seperti pada alel \&3. ${ }^{15}$ Adanya peningkatan alel $\varepsilon 4$ ini sangat erat kaitannya dengan penuaan dini otak penderita Sindrom Down yang juga merupakan faktor pencetus munculnya penyakit Alzheimer. Hampir pada semua penderita Sindrom Down setelah berumur 35 tahun ditemukan adanya plak amilod dan kekusutan neurofibriler pada otaknya seperti yang dijumpai pada penderita demensia Alzheimer. ${ }^{9,10}$ Selain itu, alel $\varepsilon 4$ memiliki andil yang besar dengan peningkatan serum kolesterol total dan pada penyakit jantung koroner. Hal ini karena alel $\varepsilon 4$ yang memiliki kandungan $\beta-V L D L$ yang tinggi dapat menghambat percabangan dan pertumbuhan neuron yang kemudian berpengaruh pada stabilitas mikrotubulus yang diperantarai oleh cell surface lipoprotein receptor, khususnya pada jalur reseptor Low Density Lipoprotein $(L D L)$.

Selain itu, yang membedakan sebaran alel gen $A P O E$ antara penderita Sindrom Down dengan populasi normal yang dalam hal ini diwakili oleh kontrol adalah pada sampel penderita Sindrom Down ditemukan alel $\varepsilon 2$ yang terlihat dari tabel 2 bahwa pada penderita Sindrom Down alel $\varepsilon 2$ memiliki frekuensi sebesar 8 sampel (12,1\%). Sementara pada populasi kontrol, tidak ditemukan yang memiliki alel $\varepsilon 2$. Alel $\varepsilon 2$ ditemukan sekitar 5-10\% pada populasi. ${ }^{19}$ Alel $\varepsilon 2$ merupakan alel gen APOE yang telah mengalami substitusi asam amino pada posisi ke 158 yang pada mulanya memiliki rangkaian basa AGCGCC menjadi AGTGCC, sehingga asam amino yang semula arginin pada posisi tersebut berubah menjadi sistein. Sedangkan pada posisi ke 112 rangkaian basanya tetap ACGTGT seperti pada alel $\varepsilon 3 .{ }^{15}$ Alel $\varepsilon 2$ dapat meningkatkan percabangan dan pertumbuhan neuron sehingga memiliki efek proteksi terhadap penyakit Alzheimer dan berhubungan dengan kelangsungan hidup yang lebih panjang pada penderita Alzheimer. ${ }^{19}$ Namun, individu dengan alel $\varepsilon 2$ sangat rentan untuk mengalami gangguan genetika hiperlipoproteine mia tipe III sehingga meningkatkan resiko untuk atherosklerosis. $^{20}$

Disamping sebaran frekuensi alel, ternyata juga ditemukan perbedaan dalam hal distribusi genotip gen $A P O E$ antara penderita Sindrom Down dibandingkan dengan populasi kontrol normal. Secara keseluruhan, baik sampel penderita Sindrom Down maupun sampel kontrol normal memiliki frekuensi genotip $\varepsilon 3 / \varepsilon 3$ paling tinggi dibandingkan dengan frekuensi genotip gen APOE lainnya. Hal ini terlihat dari tabel 3 yang menunjukkan sebaran frekuensi kombinasi genotip gen APOE, pada sampel Sindrom down genotip $\varepsilon 3 / \varepsilon 3$ memiliki frekuensi sebesar 27 sampel $(81,8 \%)$. Sementara pada populasi kontrol normal, seluruh sampel $100 \%$ memiliki genotip $\varepsilon 3 / \varepsilon 3$.

Genotip $\varepsilon 3 / \varepsilon 3$ merupakan genotip yang paling sering ditemukan yaitu sekitar $50-70 \%$ dari seluruh populasi. $^{19}$ Genotip $\varepsilon 3 / \varepsilon 3$ didapatkan dari hasil persilangan dari sesama alel $\varepsilon 3$, sehingga individu dengan genotip ini memiliki kecenderungan untuk memiliki kemampuan yang lebih baik dalam hal mengambil sisa lemak yang terjadi akibat degenerasi neuron dan menyalurkannya kepada sel-sel yang membutuhkan lemak untuk proliferasi, perbaikan membran atau remielisasi pada akson baru. ${ }^{2}$ 
Sehubungan dengan hal tersebut, pada sampel penderita Sindrom Down ditemukan genotip $\varepsilon 2 / \varepsilon 4$. Hal ini terlihat dari tabel 3 yang menunjukkan sebaran frekuensi kombinasi genotip gen $A P O E$, pada sampel Sindrom Down genotip $\varepsilon 2 / \varepsilon 4$ memiliki frekuensi sebesar 4 sampel $(12,1 \%)$. Sementara pada populasi kontrol, tidak ditemukan genotip $\varepsilon 2 / \varepsilon 4$.

Genotip $\varepsilon 2 / \varepsilon 4$ didapatkan dari hasil persilangan dari kombinasi alel $\varepsilon 2$ dan alel $\varepsilon 4$. Individu pembawa alel $\varepsilon 4$ menunjukkan peningkatan jumlah, ukuran dan densitas plak amiloid dan mereka menunjukkan peningkatan kadar $\beta$-amiloid dalam otak. ${ }^{22,23}$ Sehubungan dengan hal tersebut, individu dengan kombinasi genotip yang memiliki unsur alel $\varepsilon 4$, yaitu genotip $\varepsilon 2 / \varepsilon 4, \varepsilon 3 / \varepsilon 4$, dan $\varepsilon 4 / \varepsilon 4$ memiliki resiko kematian yang lebih tinggi dibandingkan dengan genotip $\varepsilon 2 / \varepsilon 2$, $\varepsilon 2 / \varepsilon 3$, dan $\varepsilon 3 / \varepsilon 3 .{ }^{24}$

Selain itu,yang membedakan sebaran genotip gen $A P O E$ antara penderita Sindrom Down dengan populasi normal yang dalam hal ini diwakili oleh kontrol adalah pada sampel penderita Sindrom Down terdapat genotip $\varepsilon 2 / \varepsilon 2$. Hal ini terlihat dari tabel 3 yang menunjukkan sebaran frekuensi kombinasi genotip gen $A P O E$, pada penderita Sindrom Down genotip $\varepsilon 2 / \varepsilon 2$ memiliki frekuensi sebesar 2 sampel $(6,1 \%)$. Sementara pada populasi kontrol normal, seluruh sampel tidak ada $(0 \%)$ yang memiliki genotip $\varepsilon 2 / \varepsilon 2$.

Genotip $\varepsilon 2 / \varepsilon 2$ didapatkan dari hasil persilangan dari sesama alel $\varepsilon 2$. Individu dengan suatu kombinasi genotip $\varepsilon 2 / \varepsilon 2$ memiliki sifat genetika kesulitan dalam membersihkan lemak yang masuk kedalam tubuh melalui makanan dan menjadi resiko yang lebih hebat untuk mendapatkan penyakit pembuluh darah lebih awal dan hal ini telah dibuktikan melalui penelitian bahwa $94.4 \%$ dari penderita tipe III hiperlipoproteinemia tipe III memiliki kombinasi genotip $\varepsilon 2 / \varepsilon 2$, sementara hanya sekitar $2 \%$ dari populasi yang memiliki kombinasi genotip $\varepsilon 2 / \varepsilon 2$ yang tidak menderita penyakit tersebut. $^{20}$

Selain polimorfisme gen APOE, proses penuaan otak yang lebih dini dan resiko yang lebih tinggi untuk menderita penyakit Alzheimer pada penderita Sindrom Down sangat erat kaitannya dengan kelebihan ekspresi pada kromosom 21. Pada penderita Sindrom Down hal ini sangat mudah dipahami karena mereka mengalami salinan tambahan pada kromosom 21 baik sebagian maupun secara keseluruhan sehingga dapat meningkatkan hampir separuh jumlah gen kromosom 21. ${ }^{1,25}$

Otak penderita Alzheimer ditemukan peptida $A \beta$ yang merupakan komponen mayor deposit amiloid patologis yang dikodekan oleh gen APP ( Protein Prekursor Amiloid) yang terletak pada kromosom 21. Jumlah $\beta$ Amiloid patologis akan semakin meningkat bila terjadi mutasi pada gen APP, selain itu peptida yang dihasilkan akan menjadi lebih panjang dan lengket sehingga ketika fragmen peptida tersebut dilepaskan dari sel mereka akan berakumulasi di otak dan membentuk gumpalan yang disebut plak amiloid yang merupakan karakteristik dari penyakit Alzheimer. ${ }^{26}$

Namun, bila dibandingkan dengan kelebihan ekspresi gen APP pada kromosom 21, gen APOE memiliki peran yang lebih kompleks dalam kaitannya dengan penuaan otak dini dan penyakit Alzheimer pada penderita Sindrom Down. Gen APOE selain dapat memicu polimerisasi peptida $\beta$ amiloid yang berujung pada pembentukan plak amiloid juga berkaitan dengan mitosis dan segregasi kromosom. Segregasi kromosom ini selain disebabkan oleh mutasi genetik juga dipengaruhi oleh agen-agen eksogen yang akhirnya berujung pada kegagalan pemisahan kromosom.

Banyak hal yang dapat menjadi faktor pencetus terjadinya penuaan otak dini pada penderita Sindrom Down. Sehubungan dengan hal itu keterbatasan pada penelitian ini adalah gen - gen yang berperan dalam proses penuaan ini belum dapat dianalisa secara keseluruhan. Selain itu polimorfisme gen $A P O E$ sangat erat kaitannya dengan penurunan fungsi kognitif pada penderita Sindrom Down, pada penelitian ini belum dilakukan analisa karakteristik fisik dan kognitif pada penderita Sindrom Down yang mengalami polimorfisme gen $A P O E$ sehingga belum ada pembuktian secara ilmiah mengenai dampak langsung polimorfisme gen APOE dengan penurunan fungsi kognitif penderita Sindrom Down.

\section{SIMPULAN DAN SARAN}

Dari hasil penelitian tersebut didapatkan simpulan bahwa terdapat perbedaan pola distribusi frekuensi alel gen $A P O E$ pada penderita Sindrom Down trisomi 21 di dibandingkan dengan kelompok kontrol. Penderita Sindown Down memiliki peluang 2x lebih besar dibandingkan kontrol untuk memiliki alel $\varepsilon 2$ dan $\varepsilon 4$. Selain itu juga terdapat perbedaan pola distribusi kombinasi genotip gen $A P O E$ pada penderita Sindrom Down trisomi 21 di dibandingkan dengan kelompok kontrol. Penderita Sindown Down memiliki peluang $2 x$ lebih besar dibandingkan kontrol untuk memiliki genotip $\varepsilon 2 / \varepsilon 2, \varepsilon 2 / \varepsilon 3, \varepsilon 2 / \varepsilon 4, \varepsilon 3 / \varepsilon 4$, dan $\varepsilon 4 / \varepsilon 4$. Alel $\varepsilon 3$ merupakan alel yang dominan baik pada penderita Sindrom down trisomi 21 maupun pada kontrol.

Polimorfisme gen APOE pada penderita Sindrom Down dipengaruhi oleh banyak faktor, perlu diadakan penelitian lebih lanjut untuk menganalisa faktor-faktor yang berperan pada kejadian proses penuaan dini pada penderita Sindrom Down. Selain itu, polimorfisme gen $A P O E$ sangat erat kaitannya dengan penuaan dini dan penurunan fungsi kognitif pada penderita Sindrom Down, untuk itu perlu penelitian lebih lanjut yang menganalisa karakteristik fisik dan kognitif pada penderita Sindrom Down yang mengalami polimorfisme gen APOE.

\section{UCAPAN TERIMA KASIH}

Penulis mengucapkan terima kasih kepada segenap staf Center for Biomedical Research (CEBIOR) Fakultas Kedokteran UNDIP Semarang.

\section{Daftar Pustaka}

1. Schupf N, Sergievsky GH. Genetic and host factors for dementia in Down's syndrome. $\mathrm{Br}$. J. Psychiatry; 2002. 180: p. 405-10.

2. Huether CA, Ivanovich J, Goodwin BS, Krivchenia EL, Hertzberg V, Edmonds LD et al. Maternal age specific risk rate estimates for Down syndrome among live births in whites and other races from Ohio and metropolitan Atlanta, 1970-1989. J Med Genet; 1998. 35 (6): p. 482-90.

3. Thuline HC, Pueschel SM. Cytogenetics in Down syndrome. In: Pueschel SM, Rynders JE. Down Syndrome. Advances in Biomedicine and the behavioral Sciences. Cambridge: Ware Press (pub.).1982 
4. Liptak, Gregory S. "Down Syndrome (Trisomy 21; Trisomy G)". Merck Manual; December 2008. Retrieved 2010-12-04. "Symptoms".

5. Del Bo R, Comi GP, Bresolin N, Castelli E, Conti E, Degiuli $A$ et al. The apolipoprotein $E$ $\varepsilon 4$ allele cause a faster decline of cognitive performances in Down's Syndrome. Journal of the neurologucal science; 1997. 145: p.87 -91 .

6. Houlden H, Greenwood R. Apolipoprotein E4 and traumatic brain injury. $J$ Neurol Neurosurg Psychiatry; 2006. 77: p.1106-7

7. Lai F, Kammann E, Rebeck GW, Anderson A, Chen Y, Nixon RA. APOE genotype and gender effects on Alzheimer disease in 100 adults with Down syndrome. Neurology; 1999. 53: p.331-6.

8. Hsiung A.G, Sadovnick D, Feldman H. Apolipoprotein $\mathrm{E} \varepsilon 4$ genotype as a risk factor for cognitive decline and dementia: data from the Canadian Study of Health and Aging. CMAJ; 2004 October 12. 171(8): p.863-7.

9. Zigman WB, Jenkins EC, Tycko B, Schupf N, Silverman W. Mortality is associated with apolipoprotein $\mathrm{E}$ epsilon4 in nondemented adults with Down syndrome. Neurosci Lett; 2005. 390: p.93-7.

10. Halim H, Tjahyanto A. Demensia Alzheimer pada penderita sindrom Down. Majalah Kedokteran Damianus; 2009. 8(2): 89-94.

11. Holland AJ, Oliver C. Down's syndrome and the links with Alzheimer disease. J. Neurol. Neurosurg. Psychiatry; 1995. 59: p.111-4.

12. Hoek KS, Schlegel NC, Eichhoff OM, Widmer DS, Praetorius C, Einarsson SO et al. Novel MITF targets identified using a two-step DNA microarray strategy. Pigment Cell Melanoma Res. 21; 2008. (6): p.665-76.

13. Eisenberg DTA, Kuzawa CW, Hayes MG. Worldwide allele frequencies of the human apoliprotein E (APOE) gene: climate, local adaptations and evolutionary history. American Journal of Physical Anthropology ; 2010. 143(1): 100-11.

14. Zuo $L$, van Dyck $\mathrm{CH}$, Luo $\mathrm{X}$, Kranzler $\mathrm{HR}$, Yang BZ, Gelernter J. Variation at APOE and STH lokus and Alzheimer disease. Behav Brain Funct; 2006. 2: p.13.

15. Ghebranious N, Ivacic L, Mallum J, Dokken C. Detection of APOE E2, E3 and E4 alleles using MALDI-TOF mass spectrometry and the homogeneous mass-extend technology. Nucleic Acids Res; 2005. 33: p.149.

16. Wilson PWF, Schaefer EJ, Larson MG, Ordovas JM. Apolipoprotein E alleles and risk of coronary disease a meta-analysis. Arterioscler Thromb Vasc Biol; 1996 16:p.1250-55.

17. Raber J, Wong D, Yu GQ, Buttini M, Mahley RW, Pitas RE et al. Apolipoprotein E and cognitive performance. Nature; 2000. 404: p.352- 4

18. Nathan BP, Orth M, Dong LM, Mahley RW, Pitas R. Stable expression and secretion of Apolipoprotein E3 and E4 in mouse neuroblastoma cells produces differential effects on Neurite Outgrowth. J, Biol. Chem; 1995. p.2270, $27063-71$.
19. Schachter F, Faure-Delanef L, Guenot F, Rouger H, Froguel P, Lesueur-Ginot $L$ et al. Genetic associations with human longevity at the apo $E$ and ACE lokus. Nat Genet; 1994.6:p.29-32.

20. Breslow JL, Zannis VI, SanGiacomo TR, Third JL, Tracy T, Glueck CJ. Studies of familial type III hyperlipoproteinemia using as a genetic marker the APOE phenotype E2/2. J. Lipid Res; 1982. 23 (8): p. 24-1235.

21. Mulder C, Scheltens P, Visser JJ, van Kamp GJ, Schutgens RB. Genetic and biochemical markers for Alzheimer disease : recent development. Ann Clin Biochem; 2000. 37 : p.593 - 607

22. Mann DM, Iwatsubo T, Pickering-Brown SM, Owen F, Saido TC, Perry RH. Preferential deposition of amiloid beta protein (Abeta) in the form Abeta40 in Alzheimer disease is associated with a gene dosage effect of the apolipoprotein E E4 allele. Neurosci. Lett; 1997. 221: p.81-4.

23. Laskowitz DT, Horsburgh K, Roses AD. Apolipoprotein $\mathrm{E}$ and the CNS response to injury. J. Cereb. Blood. Flow Metab; 1998. 18: p.465-71.

24. Poirier J. Apolipoprotein $\mathrm{E}$ in animal models of CNS injury and in Alzheimer disease. Trends Neurosci; 1994. 17: p.525-30.

25. Schweber M. A possible unitary genetic hypothesis for Alzheimer disease and Down syndrome. Ann NY Acad Sci; 1985. 450: p.223-38.

26. Schweber MS. Alzheimer disease related disorders. San Diego: Alan R Liss, Inc; 1989. p.247-67.

27. Martyn CN, Barker DJ, Osmond C, Harris EC, Edwardson JA, Lacey RF. Geographical relation between Alzheimer disease and aluminium in drinking water. Lancet; January 1989. P.59-62. 